\title{
Emerging targeted therapies for castration-resistant prostate cancer
}

\author{
Vincenzo Adamo*, Laura Noto, Tindara Franchina, Giuseppe Chiofalo, Maria Picciotto, Giuseppe Toscano \\ and Nicola Caristi
}

Integrated Therapies in Oncology Unit, Department of Human Pathology, University of Messina, Messina, Italy

Edited by:

Carmen Priolo, Brigham and Women's Hospital, USA

Reviewed by:

Daniele Santini, University Campus

Bio-Medico, Italy

Kevin Courtney, UT Southwestern

Medical Center, USA

*Correspondence:

Vincenzo Adamo, Integrated

Therapies in Oncology Unit,

Department of Human Pathology,

University of Messina, Via Consolare

Valeria 1, 98125 Messina, Italy.

e-mail:vadamo@unime.it
Until recently, few therapeutic options were available for patients with castration-resistant prostate cancer (CRPC). Since 2010, four new molecules with a demonstrated benefit (sipuleucel-T, cabazitaxel, abiraterone, and denosumab) have been approved in this setting, and to-date several other agents are under investigation in clinical trials. The purpose of this review is to present an update of targeted therapies for CRPC. Presented data are obtained from literature and congress reports updated until December 2011. Targeted therapies in advanced phases of clinical development include novel androgen signaling inhibitors, inhibitors of alternative signaling pathways, anti-angiogenic agents, inhibitors that target the bone microenvironment, and immunotherapeutic agents. Radium-223 and MDV3100 demonstrated a survival advantage in phase III trials and the road for their introduction in clinical practice is rapidly ongoing. Results are also awaited for phase III studies currently underway or planned with new drugs given as monotherapy (TAK-700, cabozantinib, tasquinimod, PROSTVAC-VF, ipilimumab) or in combination with docetaxel (custirsen, aflibercept, dasatinib, zibotentan). The optimal timing, combination, and sequencing of emerging therapies remain unknown and require further investigation. Additionally, the identification of novel markers of response and resistance to these therapies may better individualize treatment for patients with CRPC.

Keywords: castration-resistant prostate cancer, targeted therapy, hormonal therapy, anti-angiogenic therapy, bone targeting therapy, immunotherapy

\section{INTRODUCTION}

Prostate cancer (PC) is a major public health problem worldwide. In recent years an increasing incidence has been reported, mainly due to both population aging and improvement of diagnostic screening. In United States it represents the most common cancer type and the second cause of cancer death among men, with about 240,000 estimated new cases and 33,000 estimated deaths in 2011 (Siegel et al., 2011). Different therapeutic approaches, including surgery, radiation therapy, and androgen deprivation therapy (ADT) with luteinizing hormone-releasing hormone (LHRH) analogs and/or antiandrogens, have become the gold standard treatment for hormone-dependent PC. Chemotherapy represents, instead, the main therapeutic option in the occurrence of castration-resistant PC (CRPC), defined as disease progressing even in the presence of castration levels of circulating androgens. In this case, docetaxel $75 \mathrm{mg} / \mathrm{m}^{2}$ every 3 weeks plus prednisone $5 \mathrm{mg}$ twice daily (BID) represents the standard firstline treatment since 2004, when two phase III trials (Petrylak et al., 2004; Tannock et al., 2004) showed a prolongation of overall survival (OS) compared with mitoxantrone. Until 2010, there has been no standard second-line treatment for patients progressing on docetaxel-based therapy. The expanding knowledge of the important molecular pathways involved in PC progression has provided the opportunity to investigate specific therapeutics for these patients. Therefore, new therapeutic options have been very recently introduced into clinical practice, while other emerging molecules have shown hopeful results. The aim of this review is to summarize the most important new findings for metastatic CRPC (mCRPC) according to the different molecular pathways and to discuss their potential influence on future management of this disease.

\section{NEW APPROVED TREATMENT OPTIONS FOR mCRPC}

Thanks to the approval of four innovative molecules by Food and Drug Administration (FDA) and European Medicines Agency (EMA), the latest 2 years have marked the beginning of a new and exciting era for the treatment of MCRPC. Based on phase III clinical trials (De Bono et al., 2010, 2011; Kantoff et al., 2010a; Fizazi et al., 2011) cabazitaxel, abiraterone acetate, sipuleucel-T, and denosumab represent available therapeutic options in this setting. Cabazitaxel is a tubulin binding agent with weak affinity for $P$-glycoprotein (Bouchet and Galmarini, 2010). Following data from the TROPIC trial, which showed an OS benefit in patients treated with cabazitaxel $25 \mathrm{mg} / \mathrm{m}^{2}$ every 3 weeks versus standard mitoxantrone after docetaxel failure (De Bono et al., 2010), FDA on June 2010 and EMA on January 2011 approved this treatment for mCRPC. Two ongoing trials (FIRSTANA and PROSELICA), are now being evaluated two different doses $\left(20\right.$ and $\left.25 \mathrm{mg} / \mathrm{m}^{2}\right)$ in pre- and post-docetaxel settings to assess if dose reduction, often required because of myelotoxicity, could affect therapeutic response. The mechanism of action of taxanes seems to involve not only microtubule stabilization and tubulin function, but also 
both androgen receptor (AR) nuclear localization and signaling inhibition (Gan et al., 2009; Jiang and Huang, 2010). This interaction may lead to a more complex and successful inhibition of cell growth, as it has been demonstrated that AR signaling is maintained in CRPC and is implicated in its progression (Attar et al., 2009). Evidence of persistent hormone dependence in mCRPC has opened the way to the development of new antiandrogens able to block testosterone synthesis not only by testes, but also by adrenal glands and prostate tumor tissue. Abiraterone acetate is an oral, selective, and irreversible inhibitor of CYP17, a critical enzyme in androgen biosynthesis, which blocks non-gonadal androgen production. Abiraterone at a dose of $1000 \mathrm{mg} /$ day in combination with prednisone $10 \mathrm{mg} /$ day was approved by FDA on April 2011 and by EMA on July 2011 for the treatment of mCRPC after a docetaxel chemotherapy following the results of the COU-AA-301 trial, which demonstrated a survival benefit for the experimental arm compared with placebo (De Bono et al., 2011). A similar placebo-controlled phase III trial (COU-AA-302) evaluating abiraterone in docetaxel-naïve patients progressing after ADT has completed accrual and will provide data about the use of this drug before chemotherapy.

Sipuleucel-T is obtained by activating patient's leukapheresed antigen-presenting cells (APCs), including dendritic cells, with a recombinant fusion protein consisting of prostatic acid phosphatase (PAP) antigen and granulocyte-macrophage colonystimulating factor (GM-CSF), an immune-cell activator. This cellular immunotherapy produced an advantage in terms of OS in the IMPACT study, a placebo-controlled phase III trial that led, on April 2010, to the FDA approval in patients with asymptomatic or minimally symptomatic mCRPC (Kantoff et al., 2010a). It will be important to evaluate the rational combination and proper sequencing of sipuleucel-T with these newly approved, as well as emerging (MDV3100, TAK-700, ipilimumab) agents (Sonpavde et al., 2012).

Finally, denosumab, a human monoclonal antibody against receptor activator of nuclear factor-kappa ligand (RANK-L), showed superiority in preventing skeletal-related events (SREs) versus zoledronic acid in patients with bone metastases from CRPC (Fizazi et al., 2011) and breast cancer (Stopeck et al., 2010), and non-inferiority in patients with other solid tumors, excluding multiple myeloma (Henry et al., 2011). It has therefore been approved by FDA and EMA for the prevention of SREs in patients with metastatic bone disease. In addition, denosumab was demonstrated to delay the time to first bone metastasis and to increase bone-metastasis-free survival (BMFS) in men with non-mCRPC at high risk of bone metastasis (Smith et al., 2012), confirming its potential clinical role.

\section{TARGETING THE ANDROGEN RECEPTOR PATHWAY SPECIFIC CYP17 INHIBITOR: TAK-700}

TAK-700 (orteronel) is an oral, selective, reversible, non-steroidal androgen synthesis inhibitor of the 17.20 lyase activity, one of two enzymatic reactions catalyzed by CYP17. Due to its low inhibition of 17-hydroxylase activity, administration does not require concomitant steroid replacement (Ryan and Tindall, 2011). This compound showed activity and good tolerability in a phase I/II clinical trial on chemotherapy naïve patients (Agus et al., 2011;
Mortimer et al., 2011). Phase I patients received TAK-700 escalating doses (100-600 mg BID), while phase II ones were given TAK$700300 \mathrm{mg}$ BID, $600 \mathrm{mg}$ once daily (QD), or two dose levels (400 or $600 \mathrm{mg}$ BID) plus prednisone $5 \mathrm{mg}$ BID. In the phase II portion, 97 patients received TAK-700. Most common adverse events (AEs) were fatigue $(72 \%)$, nausea $(44 \%)$, and constipation $(31 \%)$, with fatigue $(9 \%)$ and diarrhea $(3 \%)$ as most common grade $\geq 3$ AEs. TAK-700 resulted in reduced circulating testosterone and adrenal androgen dehydroepiandrosterone sulfate (DHEA-S) concentrations. Of 43 RECIST-evaluable patients, 6 had a partial response (PR), 23 had stable disease (SD), and 9 had progression disease (PD). PSA response rates ( $\geq 50 \%$ decrease) at 12 weeks were similar across treatment groups, with an overall response rate (ORR) of $53 \%$. Researchers concluded that, in patients with $\mathrm{mCRPC}$, oral TAK-700 (with/without prednisone) at doses of $\geq 300 \mathrm{mg}$ BID was active and well tolerated. Based on these positive findings, two randomized, phase III, placebo-controlled multicenter studies are currently being investigated efficacy and safety of TAK-700 $400 \mathrm{mg}$ BID plus prednisone $5 \mathrm{mg}$ BID versus placebo plus prednisone in chemotherapy naïve and docetaxel-pre-treated mCRPC patients.

\section{NEW AR ANTAGONISTS}

Ligand-independent continued activation of ARs is one of the mechanisms that allow PC cells to survive and grow in the presence of castrate androgen levels. Receptor mutations (Taplin et al., 2003), alternative splicing with synthesis of AR splice variants (Sun et al., 2010), AR encoding gene amplification (Liu et al., 2009) as well as co-activators dysregulation have been described as potential escape mechanisms implicated in CRPC progression. Firstgeneration $\mathrm{AR}$ antagonists, such as bicalutamide or flutamide, represent the standard of care for advanced PC since the eighties. However, they bind reversibly to ARs and may have androgenagonist properties, as demonstrated in cells engineered to overexpress higher AR amounts (Tran et al., 2009), limiting therapeutic activity. This has raised the need to develop more potent and efficacious molecules. In such a perspective, new antiandrogens with improved binding properties have been produced. One of these agents, MDV3100, is an oral AR antagonist small molecule that binds to ARs with higher affinity than bicalutamide, blocking AR nuclear translocation, co-activators recruitment, and DNA binding without agonist activity when AR is overexpressed (Tran et al., 2009). Unlike bicalutamide, MDV3100 do not induce expression of the AR target genes PSA and transmembrane serine protease 2 (TMPRSS2) in a pre-clinical model, indicating the absence of agonist activity in a castration-resistant setting (Tran et al., 2009). MDV3100 has demonstrated a promising clinical activity in CRPC in a phase I/II trial (Scher et al., 2010) evaluating drug escalating doses (from 30 to $600 \mathrm{mg} /$ day) on 140 patients, 65 chemotherapy naïve and 75 previously treated with docetaxel. A recent update (Higano et al., 2011) after a long-term follow-up on time to PSA and radiographic progression, confirmed a durable anti-tumor activity of MDV3100. The median time to PSA progression, defined per-protocol as a $\geq 25 \%$ increase in PSA from baseline, was not met for naïve patients and was 8 months for postchemotherapy patients. The median time to radiographic progression was 13 months for naïve and 6 months for post-chemotherapy group. MDV3100 was generally well tolerated, with fatigue as most 
frequently reported AE (Scher et al., 2010). Based on these interesting results, MDV3100 is currently being evaluated in two phase III studies, in pre- (PREVAIL) and post-docetaxel (AFFIRM) settings. AFFIRM is a randomized, placebo-controlled, double-blind, multi-national trial evaluating MDV3100 $160 \mathrm{mg} /$ day in MCRPC men previously treated with docetaxel-based chemotherapy. The primary endpoint is OS, secondary endpoints include progressionfree survival (PFS), safety, and tolerability. On November 2011, the results of a planned interim analysis performed by the Independent Data Monitoring Committee (IDMC) showed that MDV3100 produced a 4.8-month advantage in median OS compared to placebo (18.4 months for MDV3100 versus 13.6 for placebo), with a $37 \%(\mathrm{HR}=0.631)$ reduction in the risk of death in the treated population. Consequently, IDMC recommended AFFIRM early stop, and men given placebo were offered MDV3100. A full analysis of the results from AFFIRM including safety data will be soon presented. ARN-509 is a novel small molecule AR antagonist with a mechanism of action similar to that of MDV3100, which showed powerful anti-cancer activity and induced durable remission in advanced CRPC mouse models. It seems to produce higher rates and longer duration of responses than MDV3100. An ongoing phase I/II clinical trial of continuous oral ARN-509 in patients with progressive CRPC with and without prior chemotherapy was started in July 2010 (Rathkopf et al., 2011a). Finally, AZD3514, a selective AR degrading and down-regulating agent, orally available, given on a daily continuous schedule, is now being tested in a phase I clinical trial, with an estimated completion date of 2013.

\section{DUAL CYP17 INHIBITOR AND AR ANTAGONIST: TOK-001}

Some of the CYP17 inhibitors are of particular interest as they are also AR antagonists and cause receptor down-regulation. TOK001 (VN/124-1) is the first compound to show superior efficacy compared with castration in PC xenograft models (Handratta et al., 2005). It also inhibits the proliferation of hormone-resistant PC cell lines (HP-LNCaP), which are no longer sensitive to bicalutamide and have an increased AR expression (Schayowitz et al., 2008). These impressive pre-clinical data led to the development of this compound in the clinical setting. The results of the phase I/II clinical trial ARMOR1, conducted in treatment-naïve CRPC patients progressing on ADT, are awaited after its completion in July 2012.

\section{TARGETING NON-HORMONAL INTRACELLULAR MOLECULAR PATHWAYS \\ SIGNAL TRANSDUCTION PATHWAYS INHIBITORS}

There is growing evidence indicating the presence of signaling mechanisms and cross-talk between growth factor receptor pathways and AR in androgen-dependent and hormone-resistant PC cell lines (Schayowitz et al., 2008), that lead to AR regulation by signal transduction pathways and vice versa (Traish and Morgentaler, 2009). Cross-talk between AR and growth factor pathways may represent a key factor during PC progression, conferring a survival, and invasion advantage to tumor cells, together with a resistance to hormonal therapy. This mutual relationship involves epidermal growth factor receptors (EGFR and HER-2), insulin-like growth factor receptor (IGFR), fibroblast growth factor receptor (FGFR), vascular endothelial growth factor (VEGF) receptor
(VEGFR), transforming growth factor- $\beta$ (TGF $\beta$ ), phosphoinositide 3-kinase (PI3-K), Akt, and mammalian target of rapamycin (mTOR) pathways (Wen et al., 2000; Manin et al., 2002; Zhu and Kyprianou, 2008) and represents a potential target to overcome endocrine resistance. Drugs targeting EGFR and/or HER-2 did not produce significant results in CRPC (Boccardo et al., 2008; Nabhan et al., 2009; Slovin et al., 2009a; Whang et al., 2011), while mTOR inhibitors seemed to have some activity. In particular, in pre-clinical studies on cellular (Schayowitz et al., 2008; Wedel et al., 2011) and xenograft models (Morgan et al., 2008; Schayowitz et al., 2010) everolimus demonstrated positive results in combination with TOK-001 (Schayowitz et al., 2008, 2010), AEE788 (a dual VEGFR/EGFR inhibitor; Wedel et al., 2011), and docetaxel plus zoledronic acid (Morgan et al., 2008). A phase II study (Templeton et al., 2011) investigating the activity of everolimus $10 \mathrm{mg} /$ daily as first-line treatment in patients with $\mathrm{mCRPC}$ has been recently presented. Among 37 enrolled patients, 12 (32\%) remained progression-free at 12 weeks. Other phase II studies of everolimus, alone or in combination with bicalutamide, bevacizumab, or chemotherapy, as well as trials testing other mTOR inhibitors such as temsirolimus and ridaforolimus, are currently recruiting patients. IGF-1R inhibitors are also being evaluated in CRPC. Among these, cixutumumab (IMC-A12), a monoclonal antibody, is under study in a phase I/II trial in combination with temsirolimus in chemo-naïve mCRPC patients. The study has completed phase I accrual and early results have shown good tolerability (Rathkopf et al., 2011b).

\section{INHIBITORS OF SURVIVAL FACTORS}

Overexpression of proteins belonging to inhibitor of apoptosis (IAP) family, like Bcl-2, Bcl-X, survivin, and Mcl-1 (Raffo et al., 1995; Krajewska et al., 1996; Zhang et al., 2005), or of the stressinduced cytoprotective chaperone protein clusterin (Shiota et al., 2011) in PC cells is associated with disease progression, cell survival advantage, and resistance to ADT and chemotherapy-mediated apoptosis. Oblimersen, an anti-Bcl-2 antisense oligonucleotide (Sternberg et al., 2009), and AT-101, a small molecule inhibitor of the Bcl-2 family (Sonpavde et al., 2011), were studied as first-line treatment for CRPC in combination with docetaxel. However, clinical results were both negative in terms of PSA response and OS. Similarly, YM155, a small molecule suppressor of survivin, showed modest activity in taxane-pre-treated CRPC patients (Tolcher et al., 2012).

Custirsen (OGX-011) is an antisense oligonucleotide complementary to clusterin mRNA that inhibits its translation. In a randomized phase II trial (Chi et al., 2010) custirsen 640 mg intravenously weekly plus standard docetaxel as first-line treatment improved median OS in CRPC patients compared with docetaxel alone (23.8 versus 16.9 months), even if PSA and tumor response rates were similar. Another phase II trial tested custirsen in combination with mitoxantrone or docetaxel treatment as second-line therapy after progression during or within 6 months of initial docetaxel therapy (Saad et al., 2011). Pain relief was observed in 46 and $77 \%$ of patients, respectively. These rates were higher than expected, with interesting correlations between serum clusterin and survival. Two phase III studies are ongoing: SYNERGY, planned to enroll 800 patients, which will confirm whether adding 
custirsen to standard first-line docetaxel treatment slows tumor progression and enhances survival compared to chemotherapy alone, and SATURN, investigating custirsen in association with docetaxel as second-line retreatment.

\section{DUAL C-MET/VEGFR2 INHIBITOR: CABOZANTINIB}

As known, the hepatocyte growth factor/scatter factor (HGF/SF) and its receptor, the tyrosine kinase c-MET, promote tumor growth, invasion, and metastasis in several malignancies (Birchmeier et al., 2003). In PC, c-MET expression was demonstrated to be repressed by AR (Verras et al., 2007), with a consequent enhanced synthesis during ADT and in the hormone-independent state. Moreover, c-MET pathway activation is associated with progression to bone (Knudsen et al., 2002), and seems to induce a stem-like phenotype (Van Leenders et al., 2011) conferring a high invasive capacity, especially in the perimeter of prostate tumor, where this proto-oncogene is more expressed.

Cabozantinib (XL184) is an oral small molecule inhibitor of multiple kinase signaling pathways including c-MET and VEGFR2. An interim analysis of a phase II study, designed as a "randomized discontinuation" trial in patients with mCRPC, was recently presented (Hussain et al., 2011). After 12 weeks of treatment, patients with PR continued open-label cabozantinib, those with SD were blindly randomized to cabozantinib versus placebo, and those with PD discontinued treatment. Cabozantinib $100 \mathrm{mg} /$ day led to improvement of bone parameters, especially bone scan and markers, as early as week 6 . At this time, among bone evaluable patients, $86 \%$ complete or partial resolution of bone metastases and $12 \%$ stabilizations were reported. Prolonged PFS (21 versus 6 weeks) was registered in the cohort of patients undergone randomization. At week 12 disease control rate $(\mathrm{PR}+\mathrm{SD})$ was $71 \%$ with fatigue, hypertension, and hand-foot syndrome as major AEs. Based on this early clinical activity, two phase III trials are planned to test cabozantinib $60 \mathrm{mg}$ /daily in patients with mCRPC after treatment with docetaxel and abiraterone: the 306 trial with mitoxantrone/prednisone as control arm and relief of bone pain as primary endpoint, and the 307 trial, comparing cabozantinib versus prednisone with OS as primary endpoint.

\section{TARGETING ANGIOGENESIS}

Angiogenesis and VEGFR pathway play a key role in CRPC progression and metastasis (Sweeney et al., 2002; Tomic et al., 2012), as in the majority of cancers and thus several anti-angiogenic drugs are currently studied in this setting. Bevacizumab, a humanized monoclonal antibody against VEGF, was evaluated in various phase II clinical trials in combination with docetaxel, either monotherapy or associated with other agents such as thalidomide, estramustine (Di Lorenzo et al., 2008; Ning et al., 2010; Picus et al., 2011), or lenalidomide (Huang et al., 2011), showing anti-tumor activity. Nevertheless, the phase III CALGB 90401 study (Kelly et al., 2010) failed to obtain OS advantage, and important morbidity and mortality rates were seen.

Lenalidomide is an angiogenesis inhibitor similar to thalidomide with immune-modulatory effects, which was tested in the MAINSAIL, a pivotal double-blinded phase III trial designed to evaluate the efficacy and safety of docetaxel and prednisone with or without lenalidomide in CRPC patients. In November 2011,
Celgene International Sàrl announced study discontinuation, since the combination treatment would not demonstrate a statistically significant effect.

Aflibercept is a promising anti-VEGF agent, also called VEGFtrap (Lockhart et al., 2010). It is a recombinant protein consisting of the Fc portion of human IgG1 combined with the extracellular ligand-binding domains 2 and 3 of the human VEGFR 1 and 2 , now under investigation in the phase III VENICE trial. This study, testing aflibercept in combination with first-line docetaxel, has completed accrual and results are awaited.

Tasquinimod is an oral quinoline- 3 carboxamide derivative with a new anti-angiogenic and anti-tumor activity. It binds to S100A9 (Björk et al., 2009), an immune-modulatory protein expressed on myeloid-derived suppressor cells (MDSCs), important tumor microenvironment mediators of angiogenesis and tumor growth (Schmid and Varner, 2010). In a randomized prechemotherapy placebo-controlled phase II trial, an improved PFS (7.6 versus 3.3 months) was seen in patients in tasquinimod arm (Pili et al., 2011). Most frequent AEs recorded in tasquinimod group included gastrointestinal disorders, fatigue, musculoskeletal pains, and elevations of pancreatic and inflammatory biomarkers. A phase III placebo-controlled study is ongoing in a larger pre-docetaxel mCRPC population.

Given encouraging results in several phase II trials (Dror Michaelson et al., 2009; Sonpavde et al., 2010; Zurita et al., 2012), the multi-tyrosine kinase inhibitor and anti-angiogenic small molecule sunitinib was investigated in a phase III trial (SUN1120) with OS as primary endpoint in patients with progressive mCRPC after docetaxel-based chemotherapy (Michaelson et al., 2011). Nevertheless, the study was stopped for futility at the second interim analysis on September 2010. Many other drugs targeting angiogenesis are in clinical development for CRPC, including the multi-kinase inhibitor sorafenib active against c-raf, BRAF, VEGFR, platelet-derived growth factor receptor, Flt-3, c-KIT, and RET. Sorafenib showed contrasting results in phase II studies, due to discordant imaging and PSA responses (Steinbild et al., 2007; Chi et al., 2008; Aragon-Ching et al., 2009), therefore further evaluations are needed.

\section{TARGETING THE BONE MICROENVIRONMENT SrC-FAMILY KINASES INHIBITORS}

Src and Src-family kinases (SFKs) are a family of intracellular tyrosine kinases that mediate transduction of several molecular pathways implicated in PC growth, invasion, and progression (Tatarov et al., 2009). Src signaling is also involved in the development of bone metastasis, as it regulates different osteoclast functions including bone resorption (Miyazaki et al., 2004). Dasatinib is a SFK and Abl kinase inhibitor able to suppress PC cells-induced osteoclast differentiation and activity in pre-clinical models (Araujo et al., 2009; Vandyke et al., 2010). It was studied in a phase II trial (Yu et al., 2009) conducted in 47 chemotherapy naïve men with CRPC and biochemical progression. Patients were given dasatinib 100 or $70 \mathrm{mg}$ BID. Both these schedules demonstrated biologic activity, especially on bone turnover markers, but remarkable AEs including diarrhea (62\% of patients), pleural (51\%), and pericardial $(23 \%)$ effusions were recorded. The trial was amended because of toxicity and an expansion cohort of 48 patients was 
treated with dasatinib $100 \mathrm{mg}$ once daily (Yu et al., 2011). At this dose the drug confirmed a good clinical activity and had a better tolerability profile with lesser grade $3 / 4$ AEs (13\% versus $32 \%$ ), particularly $19 \%$ versus $51 \%$ pleural effusions, compared with the BID dosage. Dasatinib in combination with docetaxel has been studied in a recently published phase I/II trial (Araujo et al., 2012). Of 46 treated patients, 37 (80\%) had any PSA decrease, including 26 (57\%) who had a confirmed PSA response. Among RECIST-evaluable patients, 18 of $30(60 \%)$ had PR with a $77 \%$ of overall disease control rate $(\mathrm{PR}+\mathrm{SD})$. Parallel bone scan improvements and urinary bone resorption markers decline were also observed. The combination was well tolerated, with a decreased frequency of pleural effusion (15\%), probably due to the concomitant prednisone administration. READY, a phase III trial of docetaxel with or without dasatinib as first-line treatment of mCRPC is now ongoing. Another SFK inhibitor in clinical development for PC, saracatinib (AZD0530), showed limited clinical efficacy as monotherapy in a phase II trial (Lara et al., 2009).

\section{ENDOTHELIN-1 RECEPTOR ANTAGONISTS}

The pathogenesis of osteoblastic bone metastasis, which frequently occur in mCRPC, is characterized by dysregulation of both bone resorption and formation (Guise et al., 2006). In particular, a role has been identified for the vasoactive peptide endothelin-1 (ET1), produced by metastatic cancer cells in the microenvironment of new-formed bone, through the stimulation of the endothelin A receptor $(\mathrm{ETaR})$ and its downstream pathways in osteoblastic cells (Yin et al., 2003). Atrasentan (ABT-627), an ETaR antagonist, reduced osteoblastic bone metastases, and bone tumor burden in in vitro and in vivo pre-clinical models (Yin et al., 2003), demonstrating an additive anti-tumor effect in combination with taxanes (Akhavan et al., 2006; Banerjee et al., 2007). Despite positive effects of atrasentan monotherapy in delaying median time to disease and PSA progression, as observed in a double-blinded, randomized, placebo-controlled phase II clinical trial (Carducci et al., 2003), data from two phase III studies carried out with this agent in either non-metastatic or metastatic disease failed to show a significant benefit in time to progression (Carducci et al., 2007; Nelson et al., 2008). Similarly, the phase III SWOG 0421 trial of atrasentan plus docetaxel as first-line therapy was closed early due to failure in reaching the primary endpoints (OS and PFS). Also zibotentan (ZD4054), another ETaR antagonist, presented discordant data among a phase II trial (James et al., 2010) and two of the subsequent phase III trials. The ENTHUSE clinical trial program consists of three phase III clinical studies designed to evaluate zibotentan monotherapy in men with metastatic (ENTHUSE M1 trial 14) and non-metastatic (ENTHUSE M0 trial 15) CRPC, as well as its combination with docetaxel as first-line treatment (ENTHUSE M1C trial 33). Both ENTHUSE studies 14 (Nelson et al., 2011) and 15 (not published) were stopped following the negative results to meet primary efficacy endpoints, while ENTHUSE study 33 will be continued and full results are expected.

\section{RADIOPHARMACEUTICALS}

Unlike strontium-89 and samarium-153, beta-emitting radiopharmaceuticals approved for palliation of bone metastasis-related pain (National Comprehensive Cancer Network (NCCN), 2011), radium-223 (alpharadin) targets bone metastasis with higher energy and shorter track length alpha-radiation. This allows hematopoietic bone marrow cells to be partly spared from damage

Table 1 | Positive phase III trials with emerging therapies for CRPC.

\begin{tabular}{|c|c|c|c|c|c|}
\hline Clinical trial & Target & $\begin{array}{l}\text { Experimental } \\
\text { versus control }\end{array}$ & Population & $\begin{array}{l}\text { Primary } \\
\text { endpoint }\end{array}$ & Outcome \\
\hline $\begin{array}{l}\text { TROPIC } \\
\text { NCT00417079 }\end{array}$ & $\begin{array}{l}\text { Microtubules } \\
\text { and tubulin }\end{array}$ & $\begin{array}{l}\text { Cabazitaxel }+\mathrm{P} \text { versus } \\
\text { mitoxantrone }+\mathrm{P}\end{array}$ & $\begin{array}{l}\text { Docetaxel pre-treated } \\
\text { mCRPC }\end{array}$ & OS & $\begin{array}{l}\text { Improved OS (15.1 versus } 12.7 \text { months; } \\
H R=0.70)\end{array}$ \\
\hline $\begin{array}{l}\text { COU-AA-301 } \\
\text { NCT00638690 }\end{array}$ & CYP 17 & $\begin{array}{l}\text { Abiraterone acetate }+\mathrm{P} \\
\text { versus placebo }+\mathrm{P}\end{array}$ & $\begin{array}{l}\text { Docetaxel pre-treated } \\
\text { mCRPC }\end{array}$ & OS & $\begin{array}{l}\text { Improved OS (14.8 versus } 10.9 \text { months; } \\
H R=0.646)\end{array}$ \\
\hline $\begin{array}{l}\text { IMPACT } \\
\text { NCT00065442 }\end{array}$ & $\begin{array}{l}\text { Anti-tumor } \\
\text { immune } \\
\text { response }\end{array}$ & Sipuleucel-T versus placebo & $\begin{array}{l}\text { Asymptomatic or minimally } \\
\text { symptomatic mCRPC }\end{array}$ & OS & $\begin{array}{l}\text { Improved OS (25.8 versus } 21.7 \text { months; } \\
H R=0.775)\end{array}$ \\
\hline $\begin{array}{l}20050103 \\
\text { NCT00321620 }\end{array}$ & RANK-L & $\begin{array}{l}\text { Denosumab + placebo versus } \\
\text { zoledronic ac }+ \text { placebo }\end{array}$ & Bone metastatic CRPC & $\begin{array}{l}\text { Time to } \\
\text { first SRE }\end{array}$ & $\begin{array}{l}\text { Improved time to first SRE ( } 20.7 \text { versus } \\
17.1 \text { months; } H R=0.82 \text { ) }\end{array}$ \\
\hline $\begin{array}{l}\text { '147TRIAL } \\
\text { NCT00286091 }\end{array}$ & RANK-L & Denosumab versus placebo & $\begin{array}{l}\text { CRPC without bone } \\
\text { metastases }\end{array}$ & BMFS & $\begin{array}{l}\text { Improved BMFS ( } 29.5 \text { versus } \\
25.2 \text { months; } H R=0.85 \text { ) }\end{array}$ \\
\hline $\begin{array}{l}\text { AFFIRM } \\
\text { NCT00974311 }\end{array}$ & $\begin{array}{l}\text { Androgen } \\
\text { receptor }\end{array}$ & MDV3100 versus placebo & $\begin{array}{l}\text { Docetaxel pre-treated } \\
\text { mCRPC }\end{array}$ & OS & $\begin{array}{l}\text { Improved OS (18.4 versus } 13.6 \text { months; } \\
H R=0.631)\end{array}$ \\
\hline $\begin{array}{l}\text { ALSYMPCA } \\
\text { NCT00699751 }\end{array}$ & $\begin{array}{l}\text { Bone microen- } \\
\text { vironment }\end{array}$ & Radium-223 versus placebo & $\begin{array}{l}\text { Bone metastatic } \\
\text { symptomatic CRPC }\end{array}$ & OS & $\begin{array}{l}\text { Improved OS (14.0 versus } 11.2 \text { months; } \\
H R=0.699)\end{array}$ \\
\hline
\end{tabular}

CRPC, castration-resistant prostate cancer; P, prednisone; OS, overall survival; RANK-L, receptor activator of nuclear factor-kappa ligand; SRE, skeletal-related event; BMFS, bone metastases-free survival. 
due to radiation (Nilsson et al., 2007). A phase II trial reported minimum myelotoxicity and a significant effect on bone-alkaline phosphatase concentrations in patients treated with radium-223 versus placebo (Nilsson et al., 2007). The subsequent phase III ALSYMPCA trial was prematurely stopped in June 2011 after a preplanned interim efficacy analysis showing a significant 2.8-month OS benefit in the radium-223 arm over placebo arm $(\mathrm{HR}=0.699)$. Based on these results approval procedures are ongoing.

\section{IMMUNOTHERAPY}

In addition to sipuleucel-T, further immunotherapeutic strategies are being explored with the aim to induce a specific T-cell response against PC (Gerritsen and Sharma, 2012). However expensive costs and complex procedures represent limiting factors for the application of these new options in clinical practice. Updated results of a phase II study of a PSA-targeted poxviral vaccine, PROSTVAC-VF (rV-PSA), for patients with mCRPC, reported a $44 \%$ reduction

Table 2 | Ongoing phase III trials with emerging targeted therapies for CRPC.

\begin{tabular}{|c|c|c|c|c|c|}
\hline Clinical trial & Target & $\begin{array}{l}\text { Experimental } \\
\text { versus control }\end{array}$ & Population & $\begin{array}{l}\text { Primary } \\
\text { endpoint }\end{array}$ & Outcome \\
\hline $\begin{array}{l}\text { COU-AA-302 } \\
\text { NCT00887198 }\end{array}$ & CYP 17 & $\begin{array}{l}\text { Abiraterone acetate }+\mathrm{P} \\
\text { versus placebo }+\mathrm{P}\end{array}$ & Chemotherapy naïve mCRPC & OS, PFS & Ongoing \\
\hline C21005 NCT01193257 & CYP $17,17.20$ lyase activity & $\begin{array}{l}\text { TAK-700 }+P \text { versus } \\
\text { placebo }+P\end{array}$ & Docetaxel pre-treated mCRPC & OS & Ongoing \\
\hline C21004 NCT01193244 & CYP $17,17.20$ lyase activity & $\begin{array}{l}\text { TAK-700 }+P \text { versus } \\
\text { placebo }+P\end{array}$ & Chemotherapy naïve mCRPC & OS, rPFS & Ongoing \\
\hline PREVAIL NCT01212991 & Androgen receptor & MDV3100 versus placebo & Chemotherapy naïve mCRPC & OS, PFS & Ongoing \\
\hline SATURN NCT01083615 & Clusterin mRNA & $\begin{array}{l}\text { Custirsen }+D+P \text { versus } \\
\text { placebo }+D+P\end{array}$ & Docetaxel pre-treated mCRPC & Pain palliation & Ongoing \\
\hline $\begin{array}{l}\text { SYNERGY } \\
\text { NCT01188187 }\end{array}$ & Clusterin mRNA & $\begin{array}{l}\text { Custirsen }+D+P \text { versus } \\
\text { placebo }+D+P\end{array}$ & Chemotherapy naïve mCRPC & OS & Ongoing \\
\hline ‘306 TRIAL & c-MET and VEGFR2 & $\begin{array}{l}\text { Cabozantinib versus } \\
\text { mitoxantrone }+\mathrm{P}\end{array}$ & $\begin{array}{l}\text { Docetaxel-abiraterone } \\
\text { pre-treated mCRPC }\end{array}$ & $\begin{array}{l}\text { Bone pain } \\
\text { alleviation }\end{array}$ & Planned \\
\hline ‘307 TRIAL & c-MET and VEGFR2 & Cabozantinib versus $\mathrm{P}$ & $\begin{array}{l}\text { Docetaxel-abiraterone } \\
\text { pre-treated mCRPC }\end{array}$ & OS & Planned \\
\hline VENICE NCT00519285 & VEGFA, VEGFB, PIGF & $\begin{array}{l}\text { Aflibercept }+D+P \text { versus } \\
\text { placebo }+D+P\end{array}$ & Chemotherapy naïve mCRPC & OS & Ongoing \\
\hline NCT0123431 & $\begin{array}{l}\text { Immune-modulatory } \\
\text { protein S100A9 }\end{array}$ & Tasquinimod versus placebo & $\begin{array}{l}\text { Asymptomatic or minimally } \\
\text { symptomatic Docetaxel } \\
\text { pre-treated mCRPC }\end{array}$ & PFS & Ongoing \\
\hline READY NCT00744497 & Src and Src-family kinases & $\begin{array}{l}\text { Dasatinib }+D+P \text { versus } \\
\text { placebo }+D+P\end{array}$ & Chemotherapy naïve mCRPC & OS & Ongoing \\
\hline $\begin{array}{l}\text { ENTHUSE M1C (33) } \\
\text { NCT00617669 }\end{array}$ & Endothelin A receptor & $\begin{array}{l}\text { Zibotentan }+D+P \text { versus } \\
\text { placebo }+D+P\end{array}$ & Chemotherapy naïve mCRPC & OS & Ongoing \\
\hline $\begin{array}{l}\text { PROSPECT } \\
\text { NCT01322490 }\end{array}$ & $\begin{array}{l}\text { Anti-tumor immune } \\
\text { response }\end{array}$ & $\begin{array}{l}\text { PROSTVAC } \pm \text { GM-CSF versus } \\
\text { placebo }\end{array}$ & $\begin{array}{l}\text { Asymptomatic or minimally } \\
\text { symptomatic chemotherapy } \\
\text { naïve mCRPC }\end{array}$ & OS & Ongoing \\
\hline $\begin{array}{l}\text { CA-184-043 } \\
\text { NCT00861614 }\end{array}$ & CTLA-4 & $\begin{array}{l}\text { Ipilimumab versus placebo, } \\
\text { following a single dose of } \\
\text { radiotherapy }\end{array}$ & Docetaxel pre-treated mCRPC & OS & Ongoing \\
\hline $\begin{array}{l}\text { CA-184-095 } \\
\text { NCT01057810 }\end{array}$ & CTLA-4 & Ipilimumab versus placebo & $\begin{array}{l}\text { Asymptomatic or minimally } \\
\text { symptomatic chemotherapy } \\
\text { naïve mCRPC }\end{array}$ & OS & Ongoing \\
\hline
\end{tabular}

CRPC, castration-resistant prostate cancer; $P$, prednisone; OS, overall survival; PFS, progression-free survival; rPFS, radiographic progression-free survival; D, docetaxel; VEGFR, vascular endothelial growth factor receptor; VEGF, vascular endothelial growth factor; PIGF, placental growth factor; GM-CSF, granulocyte-macrophage colony-stimulating factor; CTLA-4, cytotoxic T-lymphocyte-associated antigen 4. 
Table 3 | Negative phase III trials with emerging targeted therapies for CRPC.

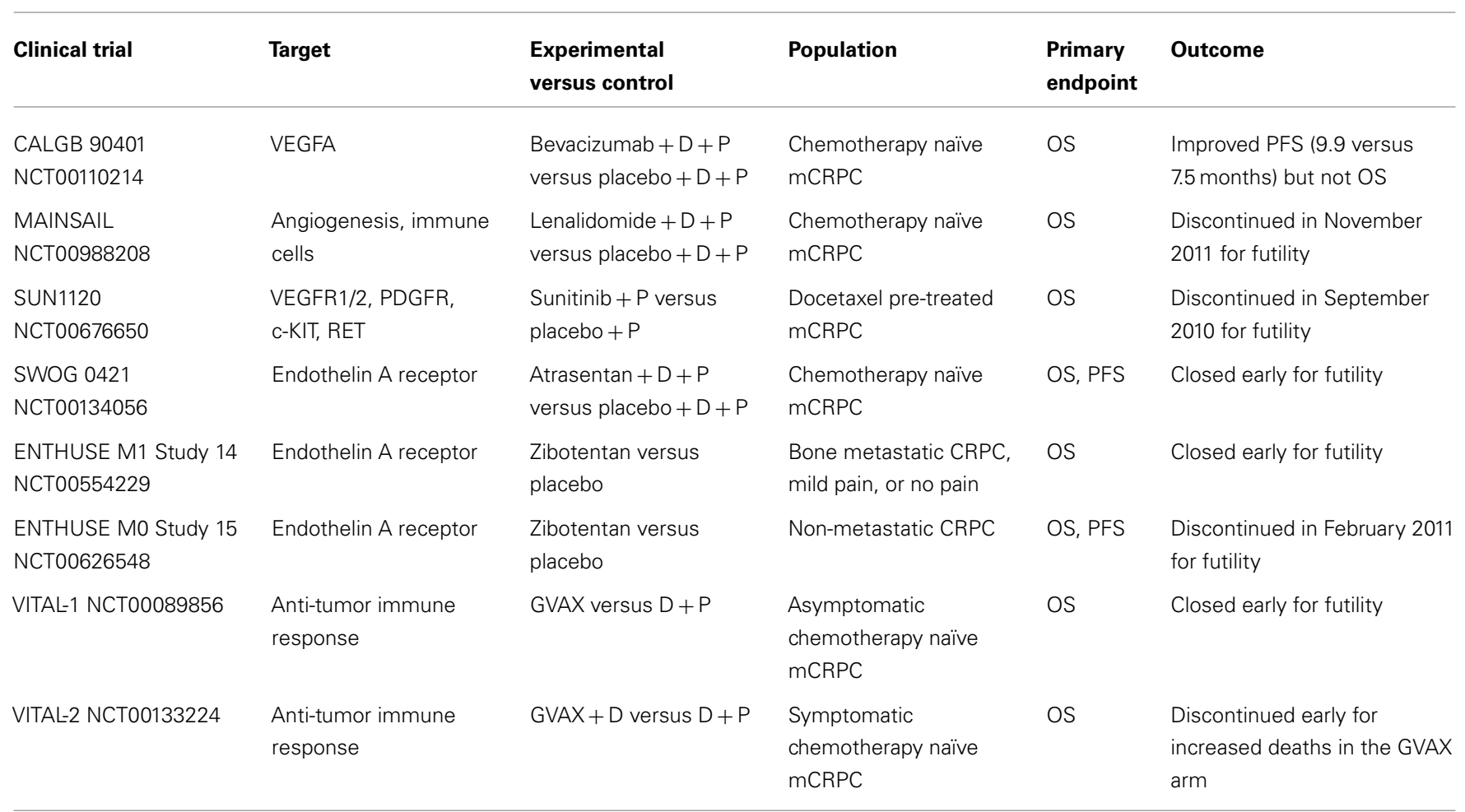

CRPC, castration-resistant prostate cancer; VEGF, vascular endothelial growth factor; $D$, docetaxel; P, prednisone; OS, overall survival; PFS, progression-free survival; VEGFR, vascular endothelial growth factor receptor; PDGFR, platelet-derived growth factor receptor.

in the death rate, and an 8.5-month improvement in median OS despite a similar PFS (Kantoff et al., 2010b). To confirm these positive data, the phase III study PROSPECT was recently initiated in patients with asymptomatic or minimally symptomatic mCRPC. GVAX is a cell-based vaccine consisting of LNCaP and PC-3 prostate cell lines, genetically engineered to secrete high levels of GM-CSF. These cells are injected intradermally in order to initiate an antiprostate immune response (Gerritsen and Sharma, 2012). Despite promising results of a phase II study (Higano et al., 2008), two phase III clinical trials, VITAL-1 and 2, were both terminated early due to futility (VITAL-1) and increased death rates (VITAL-2) in the GVAX arms (Small et al., 2009). The fully human antibody ipilimumab blocks a negative regulator of $\mathrm{T}$ cells, the cytotoxic T-lymphocyte-associated antigen 4 (CTLA-4), leading to an increased anti-tumor immune response. Early results of phase I/II clinical trials testing ipilimumab alone (Small et al., 2007) and in combination with GM-CSF (Fong et al., 2009) or radiotherapy (Slovin et al., 2009b) showed some activity. Therefore, two phase III placebo-controlled trials are being evaluated ipilimumab in CRPC patients either following radiotherapy after docetaxel chemotherapy or in chemo-naïve patients.

\section{CONCLUSION}

Prostate cancer management scenario is rapidly evolving thanks to the already approved and the emerging therapies in clinical development. Among new agents studied in phase III trials, cabazitaxel, abiraterone acetate, sipuleucel-T, MDV3100, and radium-223 have shown significant OS advantages, while denosumab has delayed time to first SRE and prolonged BMFS (Table 1). Therefore, these drugs have been or are going to be approved into clinical practice. Other agents are still under investigation in phase III trials and results are pending (Table 2). Among them, cabozantinib, custirsen, and dasatinib seem to be the most promising. However, even if all trials listed on Table 1 show positive results, they are not comparable because of heterogeneous study populations and control arms (i.e., cabazitaxel was tested versus mitoxantrone, other agents versus placebo). Further studies directly comparing these compounds are thus needed to better evaluate their clinical activity. Moreover, failure of various clinical trials testing treatment options for mCRPC (Table 3) reveals the complexity of research in this field and the related open questions. Firstly, while on one hand the availability of several novel compounds represents a meaningful tool against CRPC, on the other hand the use of multiple therapeutic strategies in these patients may confound study results, especially when OS is chosen as primary endpoint. This aspect should be taken into account when clinical trials are designed for this setting. Secondly, optimal timing, proper combination, and sequencing of the different therapeutic approaches need to be better defined. In fact, as the majority of innovative drugs have been tested in advanced stages of disease, it would be important to evaluate whether their earlier use could improve the outcomes. Moreover, until now clinical trials have been conducted in unselected populations, without regard on tumor genomic signature 
and molecular expression. In the near future, identification of different PC molecular subtypes through genomic and/or proteomic analyses, as well as prognostic and predictive markers, will allow us to exploit the potential differences in disease biology, in order to optimize therapy for each PC patient with individualized and more efficacious treatments.

\section{REFERENCES}

Agus, D. B., Stadler, W. M., Shevrin, D. H., Hart, L., MacVicar, G. R., Hamid, O., Hainsworth, J. D., Gross, M. E., Wang, J., de Leon, L., MacLean, D., and Dreicer, R. (2011). Safety, efficacy, and pharmacodynamics of the investigational agent TAK-700 in metastatic castrationresistant prostate cancer (mCRPC): updated data from a phase I/II study. J. Clin. Oncol.29(Suppl.), abstr 4531.

Akhavan, A., McHugh, K. H., Guruli, G., Bies, R. R., Zamboni, W. C., Strychor, S. A., Nelson, J. B., and Pflug, B. R. (2006). Endothelin receptor A blockade enhances taxane effects in prostate cancer. Neoplasia 8, 725-732.

Aragon-Ching, J. B., Jain, L., Gulley, J. L., Arlen, P. M., Wright, J. J., Steinberg, S. M., Draper, D., Venitz, J., Jones, E., Chen, C. C., Figg, W. D., and Dahut, W. L. (2009). Final analysis of a phase II trial using sorafenib for metastatic castration-resistant prostate cancer. BJU Int. 103, 1636-1640.

Araujo, J. C., Mathew, P., Armstrong, A. J., Braud, E. L., Posadas, E., Lonberg, M., Gallick, G. E., Trudel, G. C., Paliwal, P., Agrawal, S., and Logothetis, C. J. (2012). Dasatinib combined with docetaxel for castration-resistant prostate cancer: results from a phase 1-2 study. Cancer 118, 63-71.

Araujo, J. C., Poblenz, A., Corn, P., Parikh, N. U., Starbuck, M. W., Thompson, J. T., Lee, F., Logothetis, C. J., and Darnay, B. G. (2009). Dasatinib inhibits both osteoclast activation and prostate cancer PC3 -cell-induced osteoclast formation. Cancer Biol. Ther. 8, 2153-2159.

Attar, R. M., Takimoto, C. H., and Gottardis, M. M. (2009). Castrationresistant prostate cancer: locking-up the molecular escape routes. Clin. Cancer Res. 15, 3251-3255.

Banerjee, S., Hussain, M., Wang, Z., Saliganan, A., Che, M., Bonfil, D., Cher, M., and Sarkar, F. H. (2007). In vitro and in vivo molecular evidence for better therapeutic efficacy of ABT-627 and taxotere combination in prostate cancer. Cancer Res. 67, 3818-3826.

Birchmeier, C., Birchmeier, W., Gherardi, E., and Vande Woude, G. F. (2003). Met, metastasis, motility and more. Nat. Rev. Mol. Cell Biol. 4, 915-925.
Björk, P., Björk, A., Vogl, T., Stenström, M., Liberg, D., Olsson, A., Roth, J., Ivars, F., and Leanderson, T. (2009). Identification of human S100A9 as a novel target for treatment of autoimmune disease via binding to quinoline-3carboxamides. PLoS Biol. 7, e97. doi:10.1371/journal.pbio.1000097

Boccardo, F., Rubagotti, A., Conti, G., Battaglia, M., Cruciani, G., Manganelli, A., Ricci, S., and Lapini, A. (2008). Prednisone plus gefitinib versus prednisone plus placebo in the treatment of hormonerefractory prostate cancer: a randomized phase II trial. Oncology 74, 223-228.

Bouchet, B. P., and Galmarini, C. M. (2010). Cabazitaxel, a new taxane with favorable properties. Drugs Today 46, 735-742.

Carducci, M. A., Padley, R. J., Breul, J., Vogelzang, N. J., Zonnenberg, B. A., Daliani, D. D., Schulman, C. C., Nabulsi, A. A., Humerickhouse, R. A., Weinberg, M. A., Schmitt, J. L., and Nelson, J. B. (2003). Effect of endothelin-A receptor blockade with atrasentan on tumor progression in men with hormone-refractory prostate cancer: a randomized, phase II, placebocontrolled trial. J. Clin. Oncol. 21, 679-689.

Carducci, M. A., Saad, F., Abrahamsson, P. A., Dearnaley, D. P., Schulman, C. C., North, S. A., Sleep, D. J., Isaacson, J. D., Nelson, J. B., and Atrasentan Phase III Study Group Institutions. (2007). A phase 3 randomized controlled trial of the efficacy and safety of atrasentan in men with metastatic hormone-refractory prostate cancer. Cancer 110, 1959-1966.

Chi, K. N., Ellard, S. L., Hotte, S. J., Czaykowski, P., Moore, M., Ruether, J. D., Schell, A. J., Taylor, S., Hansen, C., Gauthier, I., Walsh, W., and Seymour, L. (2008). A phase II study of sorafenib in patients with chemonaive castration-resistant prostate cancer. Ann. Oncol. 19, 746-751.

Chi, K. N., Hotte, S. J., Yu, E. Y., Tu, D., Eigl, B. J., Tannock, I., Saad, F., North, S., Powers, J., Gleave, M. E., and Eisenhauer, E. (2010). A randomized phase II study of docetaxel and prednisone with or without OGX-011 in patients with metastatic castration-resistant prostate cancer. J. Clin. Oncol. 28, 4247-4254.
De Bono, J. S., Logothetis, C. J., Molina, A., Fizazi, K., North, S., Chu, L., Chi, K. N., Jones, R. J., Goodman, O. B. Jr., Saad, F., Staffurth, J. N., Mainwaring, P., Harland, S., Flaig, T. W. Hutson, T. E., Cheng, T., Patterson, H., Hainsworth, J. D., Ryan, C. J. Sternberg, C. N., Ellard, S. L., Fléchon, A., Saleh, M., Scholz, M., Efstathiou, E., Zivi, A., Bianchini, D. Loriot, Y., Chieffo, N., Kheoh, T., Haqq, C. M., Scher, H. I., and COUAA-301 Investigators. (2011). Abiraterone and increased survival in metastatic prostate cancer. N. Engl. J. Med. 364, 1995-2005.

De Bono, J. S., Oudard, S., Ozguroglu, M., Hansen, S., Machiels, J. P., Kocak, I., Gravis, G., Bodrogi, I., Mackenzie, M. J., Shen, L., Roessner, M., Gupta, S., Sartor, A. O., and TROPIC Investigators. (2010). Prednisone plus cabazitaxel or mitoxantrone for metastatic castrationresistant prostate cancer progressing after docetaxel treatment: a randomised open-label trial. Lancet 376, 1147-1154.

Di Lorenzo, G., Figg, W. D., Fossa, S. D., Mirone, V., Autorino, R., Longo, N., Imbimbo, C., Perdonà, S., Giordano, A., Giuliano, M., Labianca, R., and De Placido, S. (2008). Combination of bevacizumab and docetaxel in docetaxel-pretreated hormone-refractory prostate cancer: a phase 2 study. Eur. Urol. 54, 1089-1094.

Dror Michaelson, M., Regan, M. M., Oh, W. K., Kaufman, D. S., Olivier, K., Michaelson, S. Z., Spicer, B., Gurski, C., Kantoff, P. W., and Smith, M. R. (2009). Phase II study of sunitinib in men with advanced prostate cancer. Ann. Oncol. 20, 913-920.

Fizazi, K., Carducci, M., Smith, M., Damião, R., Brown, J., Karsh, L., Milecki, P., Shore, N., Rader, M., Wang, H., Jiang, Q., Tadros, S., Dansey, R., and Goessl, C. (2011). Denosumab versus zoledronic acid for treatment of bone metastases in men with castrationresistant prostate cancer: a randomised, double-blind study. Lancet 377, 813-822.

Fong, L., Kwek, S. S., O'Brien, S., Kavanagh, B., McNeel, D. G., Weinberg, V., Lin, A. M., Rosenberg, J., Ryan, C. J., Rini, B. I., and Small, E. J. (2009). Potentiating endogenous antitumor immunity to prostate cancer through combination immunotherapy with CTLA4 blockade and GM-CSF. Cancer Res. 69, 609-615.

Gan, L., Chen, S., Wang, Y., Watahiki, A., Bohrer, L., Sun, Z., Wang, Y., and Huang, H. (2009). Inhibition of the androgen receptor as a novel mechanism of taxol chemotherapy in prostate cancer. Cancer Res. 69, 8386-8394.

Gerritsen, W. R., and Sharma, P. (2012). Current and emerging treatment options for castrationresistant prostate cancer: a focus on immunotherapy. J. Clin. Immunol. 32, 25-35.

Guise, T. A., Mohammad, K. S., Clines, G., Stebbins, E. G., Wong, D. H., Higgins, L. S., Vessella, R., Corey, E., Padalecki, S., Suva, L., and Chirgwin, J. M. (2006). Basic mechanisms responsible for osteolytic and osteoblastic bone metastases. Clin. Cancer Res. 12 (20 Pt 2), 6213s$6216 \mathrm{~s}$.

Handratta, V. D., Vasaitis, T. S., Njar, V. C., Gediya, L. K., Kataria, R., Chopra, P., Newman, D. Jr., Farquhar, R., Guo, Z., Qiu, Y., and Brodie, A. M. (2005). Novel C-17-heteroaryl steroidal CYP17 inhibitors/antiandrogens: synthesis, in vitro biological activity, pharmacokinetics, and antitumor activity in the LAPC4 human prostate cancer xenograft model. J. Med. Chem. 48, 2972-2984.

Henry, D. H., Costa, L., Goldwasser, F., Hirsh, V., Hungria, V., Prausova, J., Scagliotti, G. V., Sleeboom, H., Spencer, A., Vadhan-Raj, S., von Moos, R., Willenbacher, W., Woll, P. J., Wang, J., Jiang, Q., Jun, S., Dansey, R., and Yeh, H. (2011). Randomized, double-blind study of denosumab versus zoledronic acid in the treatment of bone metastases in patients with advanced cancer (excluding breast and prostate cancer) or multiple myeloma. J. Clin. Oncol. 29, 1125-1132.

Higano, C. S., Beer, T. M., Taplin, M., Efstathiou, E., Anand, A., Hirmand, M., Fleisher, M., Scher, H. I., and Prostate Cancer Clinical Trials Consortium. (2011). Antitumor activity of MDV3100 in pre- and postdocetaxel advanced prostate cancer: long-term follow-up of a phase I/II study. J. Clin. Oncol. 29(Suppl. 7), abstr 134. 
Higano, C. S., Corman, J. M., Smith, D. C., Centeno, A. S., Steidle, C. P., Gittleman, M., Simons, J. W., Sacks, N., Aimi, J., and Small, E. J. (2008). Phase $1 / 2$ dose-escalation study of a GM-CSF-secreting, allogeneic, cellular immunotherapy for metastatic hormone-refractory prostate cancer. Cancer 113, 975-984.

Huang, X., Ning, Y. M., Gulley, J. L., Kluetz, P. G., Adelberg, D., Mulquin, M., Madan, R. A., Bassim, C., Figg, W. D., and Dahut, W. L. (2011). Phase II trial of bevacizumab (A), lenalidomide (R), docetaxel (D), and prednisone $(\mathrm{P})$ in patients (pts) with metastatic castration-resistant prostate cancer (mCRPC). J. Clin. Oncol. 29(Suppl. 7), abstr 138.

Hussain, M., Smith, M. R., Sweeney, C., Corn, P. G., Elfiky, A., Gordon, M. S., Haas, N. B., Harzstark, A. L., Kurzrock, R., Lara, P., Lin, C., Sella, A., Small, E. J., Spira, A. I., Vaishampayan, U. N., Vogelzang, N. J., Scheffold, C., Ballinger, M. D., Schimmoller, F., and Smith, D. C. (2011). Cabozantinib (XL184) in metastatic castration-resistant prostate cancer (mCRPC): results from a phase II randomized discontinuation trial. $J$. Clin. Oncol. 29(Suppl.), abstr 4516.

James, N. D., Caty, A., Payne, H., Borre, M., Zonnenberg, B. A., Beuzeboc, P., McIntosh, S., Morris, T., Phung, D., and Dawson, N. A. (2010). Final safety and efficacy analysis of the specific endothelin A receptor antagonist zibotentan (ZD4054) in patients with metastatic castration-resistant prostate cancer and bone metastases who were pain-free or mildly symptomatic for pain: a double-blind, placebocontrolled, randomized Phase II trial. BJU Int. 106, 966-973.

Jiang, J., and Huang, H. (2010). Targeting the androgen receptor by taxol in castration-resistant prostate cancer. Mol. Cell. Pharmacol. 2, 1-5.

Kantoff, P. W., Higano, C. S., Shore, N. D., Berger, E. R., Small, E. J., Penson, D. F., Redfern, C. H., Ferrari, A. C., Dreicer, R., Sims, R. B., Xu, Y., Frohlich, M. W., Schellhammer, P. F., and IMPACT Study Investigators. (2010a). Sipuleucel-T immunotherapy for castration-resistant prostate cancer. N. Engl. J. Med.363, 411-422.

Kantoff, P. W., Schuetz, T. J., Blumenstein, B. A., Glode, L. M., Bilhartz, D. L., Wyand, M., Manson, K., Panicali, D. L., Laus, R., Schlom, J., Dahut, W. L., Arlen, P. M., Gulley, J. L., and Godfrey, W. R. (2010b). Overall survival analysis of a phase II randomized controlled trial of a Poxviralbased PSA-targeted immunotherapy in metastatic castration-resistant prostate cancer. J. Clin. Oncol. 28, 1099-1105.

Kelly, W. K., Halabi, S., Carducci, M. A., George, D. J., Mahoney, J. F., Stadler, W. M., Morris, M. J., Kantoff, P., Monk III, J. P., Small, E. J., and Cancer and Leukemia Group B. (2010). A randomized, doubleblind, placebo-controlled phase III trial comparing docetaxel, prednisone, and placebo with docetaxel, prednisone, and bevacizumab in men with metastatic castrationresistant prostate cancer (mCRPC): survival results of CALGB 90401. J. Clin. Oncol. 28:18s(Suppl.), abstr LBA4511.

Knudsen, B. S., Gmyrek, G. A., Inra, J., Scherr, D. S., Vaughan, E. D., Nanus, D. M., Kattan, M. W., Gerald, W. L., and Vande Woude, G. F. (2002). High expression of the Met receptor in prostate cancer metastasis to bone. Urology 60, 1113-1117.

Krajewska, M., Krajewski, S., Epstein, J. I., Shabaik, A., Sauvageot, J., Song, K., Kitada, S., and Reed, J. C. (1996). Immunohistochemical analysis of bcl-2, bax, bcl-X, and mcl- 1 expression in prostate cancers. Am. J. Pathol. 148, 1567-1576.

Lara, P. N. Jr., Longmate, J., Evans, C. P., Quinn, D. I., Twardowski, P., Chatta, G., Posadas, E., Stadler, W., and Gandara, D. R. (2009). A phase II trial of the Src-kinase inhibitor AZD0530 in patients with advanced castration-resistant prostate cancer: a California Cancer Consortium study. Anticancer Drugs 20, 179-184.

Liu, W., Laitinen, S., Khan, S., Vihinen, M., Kowalski, J., Yu, G., Chen, L., Ewing, C. M., Eisenberger, M. A., Carducci, M. A., Nelson, W. G., Yegnasubramanian, S., Luo, J., Wang, Y., $\mathrm{Xu}$, J., Isaacs, W. B., Visakorpi, T., and Bova, G. S. (2009). Copy number analysis indicates monoclonal origin of lethal metastatic prostate cancer. Nat. Med. 15, 559-565.

Lockhart, A. C., Rothenberg, M. L., Dupont, J., Cooper, W., Chevalier, P., Sternas, L., Buzenet, G., Koehler, E., Sosman, J. A., Schwartz, L. H., Gultekin, D. H., Koutcher, J. A., Donnelly, E. F., Andal, R., Dancy, I., Spriggs, D. R., and Tew, W. P. (2010). Phase I study of intravenous vascular endothelial growth factor trap, aflibercept, in patients with advanced solid tumors. J. Clin. Oncol. 28, 207-214.

Manin, M., Baron, S., Goossens, K., Beaudoin, C., Jean, C., Veyssiere, G., Verhoeven, G., and Morel, L. (2002). Androgen receptor expression is regulated by the phosphoinositide 3kinase/Akt pathway in normal and tumoral epithelial cells. Biochem. J. 366(Pt 3), 729-736.

Michaelson, M. D., Oudard, S., Ou, Y., Sengeløv, L., Saad, F., Houede, N., Ostler, P. J., Stenzl, A., Daugaard, G., Jones, R. J., Laestadius, F., Bahl, A. Castellano, D. E., Gschwend, J., Maurina, T., Ye, D., Chen, I., Wang, S., and Maneval, E. C. (2011). Randomized, placebo-controlled, phase III trial of sunitinib in combination with prednisone $(\mathrm{SU}+\mathrm{P})$ versus prednisone (P) alone in men with progressive metastatic castration-resistant prostate cancer (mCRPC). J. Clin. Oncol. 29(Suppl.), abstr 4515.

Miyazaki, T., Sanjay, A., Neff, L., Tanaka, S., Horne, W. C., and Baron, R. (2004). Src kinase activity is essential for osteoclast function. J. Biol. Chem. 279, 17660-17666.

Morgan, T. M., Pitts, T. E., Gross, T. S., Poliachik, S. L., Vessella, R. L., and Corey, E. (2008). RAD001 (Everolimus) inhibits growth of prostate cancer in the bone and the inhibitory effects are increased by combination with docetaxel and zoledronic acid. Prostate 68, 861-871.

Mortimer, P., Gross, M., Shevrin, D., Dreicer, R., Trepicchio, W. L., MacLean, D., Webb, I., Wang, J., and Agus, D. B. (2011). Phase 1/2 study of TAK-700, an investigational 17,20-Lyase Inhibitor, in chemotherapy-naïve patients with metastatic Castration-Resistant Prostate Cancer (mCRPC): safety, efficacy, and evaluation of Circulating Tumor Cells (CTCs). Presented at the 3rd European Multidisciplinary Meeting on Urological Cancers EMUC 2011, abstr 07.

Nabhan, C., Lestingi, T. M., Galvez, A., Tolzien, K., Kelby, S. K., Tsarwhas, D., Newman, S., and Bitran, J. D. (2009). Erlotinib has moderate singleagent activity in chemotherapynaïve castration-resistant prostate cancer: final results of a phase II trial. Urology 74, 665-671.

National Comprehensive Cancer Network (NCCN). (2011). Clinical Practice Guidelines in Oncology. Prostate cancer. Version 4.2011.

Nelson, J. B., Fizazi, K., Miller, K., Higano, C. S., Moul, J. W., Morris, T., McIntosh, S., Pemberton, K. and Gleave, M. E. (2011). Phase III study of the efficacy and safety of zibotentan (ZD4054) in patients with bone metastatic castrationresistant prostate cancer (CRPC). J. Clin. Oncol. 29(Suppl. 7), abstr 117.
Nelson, J. B., Love, W., Chin, J. L., Saad, F., Schulman, C. C., Sleep, D. J., Qian, J., Steinberg, J., Carducci, M., and Atrasentan Phase 3 Study Group. (2008). Phase 3, randomized, controlled trial of atrasentan in patients with nonmetastatic, hormone-refractory prostate cancer. Cancer 113, 2478-2487.

Nilsson, S., Franzén, L., Parker, C., Tyrrell, C., Blom, R., Tennvall, J., Lennernäs, B., Petersson, U., Johannessen, D. C., Sokal, M., Pigott, K., Yachnin, J., Garkavij, M., Strang, P., Harmenberg, J., Bolstad, B., and Bruland, O. S. (2007). Bonetargeted radium-223 in symptomatic, hormone-refractory prostate cancer: a randomised, multicentre, placebo-controlled phase II study. Lancet Oncol. 8, 587-594.

Ning, Y. M., Gulley, J. L., Arlen, P. M., Woo, S., Steinberg, S. M., Wright, J. J., Parnes, H. L., Trepel, J. B., Lee, M. J., Kim, Y. S., Sun, H., Madan, R. A., Latham, L., Jones, E., Chen, C. C., Figg, W. D., and Dahut, W. L. (2010). Phase II trial of bevacizumab, thalidomide, docetaxel, and prednisone in patients with metastatic castration-resistant prostate cancer. J. Clin. Oncol. 28, 2070-2076.

Petrylak, D. P., Tangen, C. M., Hussain, M. H., Lara, P. N. Jr., Jones, J. A., Taplin, M. E., Burch, P. A., Berry, D., Moinpour, C., Kohli, M., Benson, M. C., Small, E. J., Raghavan, D., and Crawford, E. D. (2004). Docetaxel and estramustine compared with mitoxantrone and prednisone for advanced refractory prostate cancer. N. Engl. J. Med. 351, 1513-1520.

Picus, J., Halabi, S., Kelly, W. K., Vogelzang, N. J., Whang, Y. E., Kaplan, E. B., Stadler, W. M., Small, E. J., and Cancer and Leukemia Group B. (2011). A phase 2 study of estramustine, docetaxel, and bevacizumab in men with castrate-resistant prostate cancer: results from Cancer and Leukemia Group B Study 90006. Cancer 117, 526-533.

Pili, R., Häggman, M., Stadler, W. M., Gingrich, J. R., Assikis, V. J., Björk, A., Nordle, O., Forsberg, G., Carducci, M. A., and Armstrong, A. J. (2011). Phase II randomized, double-blind, placebo-controlled study of tasquinimod in men with minimally symptomatic metastatic castrate-resistant prostate cancer. J. Clin. Oncol. 29, 4022-4028.

Raffo, A. J., Perlman, H., Chen, M. W., Day, M. L., Streitman, J. S., and Buttyan, R. (1995). Overexpression of bcl-2 protects prostate cancer cells 
from apoptosis in vitro and confers resistance to androgen depletion in vivo. Cancer Res. 55, 4438-4445.

Rathkopf, D. E., Danila, D. C., Slovin, S. F., Morris, M. J., Steinbrecher, J. E., Chen, Y., Fleisher, M., Larson, S. M., Sawyers, C. L., and Scher, H. I. (2011a). A first-in-human, openlabel, phase I/II safety, pharmacokinetic, and proof-of-concept study of ARN-509 in patients with progressive advanced castration-resistant prostate cancer (CRPC). J. Clin. Oncol. 29(Suppl.), abstr TPS190.

Rathkopf, D. E., Danila, D. C., Morris, M. J., Slovin, S. F., Borwick, L. S., Momen, L., Curley, T., Arauz, G., Larson, S. M., Fleisher, M., Rosen, N., and Scher, H. I. (2011b). Anti-insulin-like growth factor-1 receptor (IGF-1R) monoclonal antibody cixutumumab (cix) plus mTOR inhibitor temsirolimus (tem) in metastatic castrationresistant prostate cancer (mCRPC): results of a phase I pilot study. J. Clin. Oncol. 29(Suppl.), abstr e15081.

Ryan, C. J., and Tindall, D. J. (2011). Androgen receptor rediscovered: the new biology and targeting the androgen receptor therapeutically. J. Clin. Oncol. 29, 3651-3658.

Saad, F., Hotte, S., North, S., Eigl, B., Chi, K., Czaykowski, P., Wood, L., Pollak, M., Berry, S., Lattouf, J. B., Mukherjee, S. D., Gleave, M., Winquist, E., and Canadian Uro-Oncology Group. (2011). Randomized phase II trial of Custirsen (OGX-011) in combination with docetaxel or mitoxantrone as second-line therapy in patients with metastatic castrateresistant prostate cancer progressing after first-line docetaxel: CUOG trial P-06c. Clin. Cancer Res. 17, 5765-5773.

Schayowitz, A., Sabnis, G., Goloubeva, O., Njar, V. C., and Brodie, A. M. (2010). Prolonging hormone sensitivity in prostate cancer xenografts through dual inhibition of $\mathrm{AR}$ and mTOR. Br. J. Cancer 103, 1001-1007.

Schayowitz, A., Sabnis, G., Njar, V. C. O., and Brodie, A. M. H. (2008). Synergistic effect of a novel antiandrogen, VN/124-1, and signal transduction inhibitors in prostate cancer progression to hormone independence in vitro. Mol. Cancer Ther. 7, 121-132.

Scher, H. I., Beer, T. M., Higano, C. S., Anand, A., Taplin, M. E., Efstathiou, E., Rathkopf, D., Shelkey, J., Yu, E. Y., Alumkal, J., Hung, D., Hirmand, M., Seely, L., Morris, M. J., Danila, D. C., Humm, J., Larson, S., Fleisher, M., Sawyers, C. L., and Prostate Cancer
Foundation/Department of Defense Prostate Cancer Clinical Trials Consortium. (2010). Antitumour activity of MDV3100 in castrationresistant prostate cancer: a phase 1-2 study. Lancet 375, 1437-1446.

Schmid, M. C., and Varner, J. A. (2010). Myeloid cells in the tumor microenvironment: modulation of tumor angiogenesis and tumor inflammation. J. Oncol. 2010, 201026.

Shiota, M., Zoubeidi, A., Kumano, M., Beraldi, E., Naito, S., Nelson, C. C., Sorensen, P. H., and Gleave, M. E. (2011). Clusterin is a critical downstream mediator of stress-induced YB-1 transactivation in prostate cancer. Mol. Cancer Res. 9, 1755-1766.

Siegel, R., Ward, E., Brawley, O., and Jemal, A. (2011). Cancer statistics, 2011: the impact of eliminating socioeconomic and racial disparities on premature cancer deaths. $C A$ Cancer J. Clin. 61, 212-236.

Slovin, S. F., Kelly, W. K., Wilton, A., Kattan, M., Myskowski, P., Mendelsohn, J., and Scher, H. I. (2009a). Anti-epidermal growth factor receptor monoclonal antibody cetuximab plus Doxorubicin in the treatment of metastatic castration-resistant prostate cancer. Clin. Genitourin. Cancer 7, E77-E82.

Slovin, S. F., Beer, T. M., Higano, C. S., Tejwani, S., Hamid, O., Picus, J., Harzstark, A., Scher, H. I., Lan, Z., Lowy, I., and Prostate Cancer Clinical Trials Consortium. (2009b). Initial phase II experience of ipilimumab (IPI) alone and in combination with radiotherapy (XRT) in patients with metastatic castrationresistant prostate cancer (mCRPC). J. Clin. Oncol. 27(Suppl. 15s), abstr 5138.

Small, E., Demkow, T., Gerritsen, W. R., Rolland, F., Hoskin, P., Smith, D. C., Parker, C., Chondros, D., Ma, J., and Hege, K. (2009). A phase III trial of GVAX immunotherapy for prostate cancer in combination with docetaxel versus docetaxel plus prednisone in symptomatic, castrationresistant prostate cancer (CRPC). Presented at the American Society of Clinical Oncology 2009 Genitourinary Cancers Symposium, abstr 7.

Small, E. J., Tchekmedyian, N. S., Rini, B. I., Fong, L., Lowy, I., and Allison, J. P. (2007). A pilot trial of CTLA-4 blockade with human anti-CTLA-4 in patients with hormone-refractory prostate cancer. Clin. Cancer Res. 13, 1810-1815.

Smith, M. R., Saad, F., Coleman, R., Shore, N., Fizazi, K., Tombal, B., Miller, K., Sieber, P., Karsh, L., Damião, R., Tammela, T. L., Egerdie,
B., Van Poppel, H., Chin, J., Morote, J., Gómez-Veiga, F., Borkowski, T., Ye, Z., Kupic, A., Dansey, R., and Goessl, C. (2012). Denosumab and bonemetastasis-free survival in men with castration-resistant prostate cancer: results of a phase 3, randomised, placebo-controlled trial. Lancet 379 , 39-46.

Sonpavde, G., Di Lorenzo, G., Higano, C. S., Kantoff, P. W., Madan, R., Shore, N. D., and Sternberg, C. N. (2012). The role of sipuleucel$\mathrm{T}$ in therapy for castration-resistant prostate cancer: a critical analysis of the literature. Eur. Urol. 61, 639-647.

Sonpavde, G., Matveev, V., Burke, J. M. Caton, J. R., Fleming, M. T., Hutson, T. E., Galsky, M. D., Berry, W. R., Karlov, P., Holmlund, J. T., Wood, B. A., Brookes, M., and Leopold, L. (2011). Randomized phase II trial of docetaxel plus prednisone in combination with placebo or AT-101, an oral small molecule Bcl-2 family antagonist, as first-line therapy for metastatic castration-resistant prostate cancer. Ann. Oncol. PMID: 22112969. [Epub ahead of print].

Sonpavde, G., Periman, P. O., Bernold, D., Weckstein, D., Fleming, M. T., Galsky, M. D., Berry, W. R., Zhan, F., Boehm, K. A., Asmar, L., and Hutson, T. E. (2010). Sunitinib malate for metastatic castration-resistant prostate cancer following docetaxelbased chemotherapy. Ann. Oncol. 21 , 319-324.

Steinbild, S., Mross, K., Frost, A., Morant, R., Gillessen, S., Dittrich, C., Strumberg, D., Hochhaus, A. Hanauske, A. R., Edler, L., Burkholder, I., and Scheulen, M. (2007). A clinical phase II study with sorafenib in patients with progressive hormone-refractory prostate cancer: a study of the CESAR Central European Society for Anticancer Drug Research-EWIV. Br. J. Cancer 97, 1480-1485.

Sternberg, C. N., Dumez, H., Van Poppel, H., Skoneczna, I., Sella, A., Daugaard, G., Gil, T., Graham, J., Carpentier, P., Calabro, F., Collette, L., Lacombe, D., and EORTC Genitourinary Tract Cancer Group. (2009). Docetaxel plus oblimersen sodium (Bcl-2 antisense oligonucleotide): an EORTC multicenter, randomized phase II study in patients with castration-resistant prostate cancer. Ann. Oncol. 20, 1264-1269.

Stopeck, A. T., Lipton, A., Body, J. J., Steger, G. G., Tonkin, K., de Boer, R. H., Lichinitser, M., Fujiwara, Y., Yardley, D. A., Viniegra, M., Fan, M., Jiang, Q., Dansey, R., Jun, S., and Braun,
A. (2010). Denosumab compared with zoledronic acid for the treatment of bone metastases in patients with advanced breast cancer: a randomized, double-blind study. J. Clin. Oncol. 28, 5132-5139.

Sun, S., Sprenger, C. C. T., Vessella, R. L., Haugk, K., Soriano, K., Mostaghel, E. A., Page, S. T., Coleman, I. M., Nguyen, H. M., Sun, H., Nelson, P. S., and Plymate, S. R. (2010) Castration resistance in human prostate cancer is conferred by a frequently occurring androgen receptor splice variant. J. Clin. Invest. 120, 2715-2730.

Sweeney, P., Karashima, T., Kim, S. J., Kedar, D., Mian, B., Huang, S., Baker, C., Fan, Z., Hicklin, D. J., Pettaway, C. A., and Dinney, C. P. (2002). Antivascular endothelial growth factor receptor 2 antibody reduces tumorigenicity and metastasis in orthotopic prostate cancer xenografts via induction of endothelial cell apoptosis and reduction of endothelial cell matrix metalloproteinase type 9 production. Clin. Cancer Res. 8, 2714-2724.

Tannock, I. F., de Wit, R., Berry, W. R., Horti, J., Pluzanska, A., Chi, K. N., Oudard, S., Théodore, C., James, N. D., Turesson, I., Rosenthal, M. A., Eisenberger, M. A., and TAX 327 Investigators. (2004). Docetaxel plus prednisone or mitoxantrone plus prednisone for advanced prostate cancer. N. Engl. J. Med. 351, 1502-1512.

Taplin, M. E., Rajeshkumar, B., Halabi, S., Werner, C. P., Woda, B. A., Picus, J., Stadler, W., Hayes, D. F., Kantoff, P. W., Vogelzang, N. J., and Small, E. J. (2003). Androgen receptor mutations in androgenindependent prostate cancer: cancer and leukemia group B study 9663. J. Clin. Oncol. 21, 2673-2678.

Tatarov, O., Mitchell, T. J., Seywright, M., Leung, H. Y., Brunton, V. G., and Edwards, J. (2009). SRC family kinase activity is up-regulated in hormone-refractory prostate cancer. Clin. Cancer Res. 15, 3540-3549.

Templeton, A., Rothermundt, C., Cathomas, R., Baertschi, D., Droege, C., Gautschi, O., Borner, M. M., Fechter, E., Stenner, F., Winterhalder, R. C., Mueller, B., Dutoit V., Dietrich, P., Schiess, R., Wild, P., Thalmann, G. N., Klingbiel, D. and Gillessen, S. (2011). Everolimus as first-line therapy in nonrapidly progressive metastatic castrationresistant prostate cancer (mCRPC): a multicenter phase II trial (SAKK 08/08). J. Clin. Oncol. 29(Suppl.), abstr 4588 . 
Tolcher, A. W., Quinn, D. I., Ferrari, A., Ahmann, F., Giaccone, G., Drake, T., Keating, A., and de Bono, J. S. (2012). A phase II study of YM155, a novel small-molecule suppressor of survivin, in castration-resistant taxane-pretreated prostate cancer. Ann. Oncol. 23, 968-973.

Tomic, T. T., Gustavsson, H., Wang, W., Jennbacken, K., Welén, K., and Damber, J. E. (2012). Castration resistant prostate cancer is associated with increased blood vessel stabilization and elevated levels of VEGF and Ang-2. Prostate 72, 705-712.

Traish, A. M., and Morgentaler, A. (2009). Epidermal growth factor receptor expression escapes androgen regulation in prostate cancer: a potential molecular switch for tumour growth. Br. J. Cancer 101, 1949-1956.

Tran, C., Ouk, S., Clegg, N. J., Chen, Y., Watson, P. A., Arora, V., Wongvipat, J., Smith-Jones, P. M., Yoo, D., Kwon, A., Wasielewska, T., Welsbie, D., Chen, C. D., Higano, C. S., Beer, T. M., Hung, D. T., Scher, H. I., Jung, M. E., and Sawyers, C. L. (2009). Development of a secondgeneration antiandrogen for treatment of advanced prostate cancer. Science 324, 787-790.

Van Leenders, G. J., Sookhlall, R., Teubel, W. J., de Ridder, C. M., Reneman, S., Sacchetti, A., Vissers, K. J., van Weerden, W., and Jenster, G. (2011). Activation of cMET induces a stem-like phenotype in human prostate cancer. PLoS ONE 6, e26753. doi:10.1371/journal.pone. 0026753
Vandyke, K., Dewar, A. L., Diamond, P., Fitter, S., Schultz, C. G., Sims, N. A., and Zannettino, A. C. (2010). The tyrosine kinase inhibitor dasatinib dysregulates bone remodeling through inhibition of osteoclasts in vivo. J. Bone Miner. Res. 25, 1759-1770.

Verras, M., Lee, J., Xue, H., Li, T. H., Wang, Y., and Sun, Z. (2007). The androgen receptor negatively regulates the expression of c-Met: implications for a novel mechanism of prostate cancer progression. Cancer Res. 67, 967-975.

Wedel, S., Hudak, L., Seibel, J. M., Juengel, E., Tsaur, I., Haferkamp, A., and Blaheta, R. A. (2011). Combined targeting of the VEGFr/EGFr and the mammalian target of rapamycin (mTOR) signaling pathway delays cell cycle progression and alters adhesion behavior of prostate carcinoma cells. Cancer Lett. 301, 17-28.

Wen, Y., Hu, M. C., Makino, K., Spohn, B., Bartholomeusz, G., Yan, D. H., and Hung, M. C. (2000). HER-2/neu promotes androgenindependent survival and growth of prostate cancer cells through the Akt pathway. Cancer Res. 60, 6841-6845.

Whang, Y. E., Armstrong, A. J., Rathmell, W. K., Godley, P. A., Kim, W. Y., Pruthi, R. S., Wallen, E. M., Crane, J. M., Moore, D. T., Grigson, G., Morris, K., Watkins, C. P., and George, D. J. (2011). A phase II study of lapatinib, a dual EGFR and HER-2 tyrosine kinase inhibitor, in patients with castration-resistant prostate cancer. Urol. Oncol. PMID: 21396844. [Epub ahead of print].

Yin, J. J., Mohammad, K. S., Käkönen, S. M., Harris, S., Wu-Wong, J. R., Wessale, J. L., Padley, R. J., Garrett, I. R., Chirgwin, J. M., and Guise, T. A. (2003). A causal role for endothelin-1 in the pathogenesis of osteoblastic bone metastases. Proc. Natl. Acad. Sci. U.S.A. 100 10954-10959.

Yu, E. Y., Massard, C., Gross, M. E., Carducci, M. A., Culine, S., Hudes, G., Posadas, E. M., Sternberg, C. N., Wilding, G., Trudel, G. C., Paliwal, P., and Fizazi, K. (2011). Once-daily dasatinib: expansion of phase II study evaluating safety and efficacy of dasatinib in patients with metastatic castrationresistant prostate cancer. Urology 77, 1166-1171.

Yu, E. Y., Wilding, G., Posadas, E., Gross, M., Culine, S., Massard, C., Morris, M. J., Hudes, G., Calabrò, F. Cheng, S., Trudel, G. C., Paliwal, P., and Sternberg, C. N. (2009). Phase II study of dasatinib in patients with metastatic castration-resistant prostate cancer. Clin. Cancer Res. 15 , 7421-7428.

Zhang, M., Latham, D. E., Delaney, M. A., and Chakravarti, A. (2005). Survivin mediates resistance to antiandrogen therapy in prostate cancer. Oncogene 24, 2474-2482.

Zhu, M. L., and Kyprianou, N. (2008). Androgen receptor and growth factor signaling cross-talk in prostate cancer cells. Endocr. Relat. Cancer 15 , 841-849.
Zurita, A. J., George, D. J., Shore, N. D., Liu, G., Wilding, G., Hutson, T. E., Kozloff, M., Mathew, P., Harmon, C. S., Wang, S. L., Chen, I., Chow Maneval, E., and Logothetis, C. J. (2012). Sunitinib in combination with docetaxel and prednisone in chemotherapy-naive patients with metastatic, castrationresistant prostate cancer: a phase 1/2 clinical trial. Ann. Oncol. 23, 688-694.

Conflict of Interest Statement: The authors declare that the research was conducted in the absence of any commercial or financial relationships that could be construed as a potential conflict of interest.

Received: 30 January 2012; paper pending published: 13 April 2012; accepted: 08 May 2012; published online: 31 May 2012.

Citation: Adamo V, Noto L, Franchina $T$, Chiofalo G, Picciotto M, Toscano $G$ and Caristi $N$ (2012) Emerging targeted therapies for castration-resistant prostate cancer. Front. Endocrin. 3:73. doi: 10.3389/fendo.2012.00073

This article was submitted to Frontiers in Cancer Endocrinology, a specialty of Frontiers in Endocrinology.

Copyright (c) 2012 Adamo, Noto, Franchina, Chiofalo, Picciotto, Toscano and Caristi. This is an open-access article distributed under the terms of the Creative Commons Attribution Non Commercial License, which permits noncommercial use, distribution, and reproduction in other forums, provided the original authors and source are credited. 